\title{
Response of Output Fluctuations in Costa Rica to Exchange Rate Movements and Global Economic Conditions and Policy Implications
}

\author{
Yu Hsing (Corresponding author) \\ Department of Management \& Business Administration, Southeastern Louisiana University \\ SLU 10813, Hammond, LA 70402, USA \\ Tel: 1-985-549-2086Ｅ-mail: yhsing@selu.edu
}

Antoinette S. Phillips

Department of Management \&Business Administration, Southeastern Louisiana University

SLU 10813, Hammond, LA 70402, USA

Tel: 1-985-549-2086_E-mail: aphillips@selu.edu

\begin{abstract}
Applying a three-equation model incorporating the monetary policy reaction function, this study finds that the real exchange rate and real GDP exhibit a bell-shaped relationship, suggesting that real depreciation raises real output during 2000.Q1-2005.Q2 whereas real appreciation increases real output during 2005.Q3-2008.Q4 or after real GDP has reached approximately 440,000 billion colones. Other findings are that a lower ratio of government consumption spending to GDP, a lower real federal funds rate, a higher world real income, and a lower expected inflation rate would increase real output. Major policy implications are that real appreciation instead of real depreciation would raise real output after 2005.Q2, that fiscal prudence needs to be followed, and that global economic conditions including world real income and the world real interest rate are important in affecting real output for Costa Rica.
\end{abstract}

Keywords: Monetary policy reaction function, Real depreciation or appreciation, Fiscal policy, World interest rate, World income, Inflation 


\section{Introduction}

Costa Rica had enjoyed a sustained economic growth with an average annual growth rate of 6.6\% during 2003-2007 mainly attributable to strong consumer and business confidence, expanding global economy, sound economic policies, prudent fiscal policy, and sound monetary policy. As a result, the economy experienced a rising real income, a lower poverty rate, a decrease in the ratio of public debt to GDP, and an increase in international net reserves (IMF, 2009). The passage of the DR-CAFTA by the Costa Rican Congress in January 2009 has reduced trade restrictions among member countries and paved the way for trade liberalization in the financial, insurance, and telecommunications sectors. However, the global financial crisis has hurt Costa Rica's economy, especially in manufacturing, construction, and financial services. According to the forecast for Costa Rica in 2009 (The Economist, 2009), real GDP expects to decline 2.5\%, the current account deficit as a percent of GDP will be $2.6 \%$, and the budget deficit as a percent of GDP will be $4.2 \%$. The inflation rate will reach $9.4 \%$. The colon exchange rate against the U.S. dollar will depreciate from 526.2 to 582.5 .

This paper examines the responses of real output to selected domestic and global economic variables with a focus on the relationship between real exchange rate movements and output fluctuations. Real depreciation may shift aggregate demand to the right due to increased net exports, shift aggregate demand to the left due to monetary tightening in response to a higher inflation rate caused by real depreciation, and shift aggregate supply to the left due to a higher inflation rate caused by a higher import price. Real appreciation may shift aggregate demand to the left due to decreased net exports, shift aggregate demand to the right due to monetary easing in response to a lower inflation rate caused by real appreciation, and shift aggregate supply to the right due to a lower inflation rate caused by a lower import price. Hence, empirical work is needed to determine whether real depreciation or appreciation would raise or reduce real output.

There are several major studies examining the impact of currency depreciation or devaluation on output. Krugman and Taylor (1978) indicate that if exports are initially less than imports, currency devaluation would have a contractionary impact. Edwards (1986), Upadhyaya (1999), Bahmani-Oskooee, Chomsisengphet, and Kandil (2002) and Christopoulos (2004) show that the impact of currency devaluation or depreciation on real output could be contractionary, expansionary, or neutral. Chou and Chao (2001) and Bahmani-Oskooee and Kutan (2008) reveal that devaluation or depreciation is not effective or has little effect over the long run.

Some studies indicate that devaluation or depreciation is expansionary [Gylfason and Schmid (1983) except for the U.K. and Brazail, Gylfason and Risager (1984) for developed countries, and Bahmani-Oskooee and Rhee (1997)]. On the other hand, other studies show that devaluation or depreciation is contractionary [Gylfason and Risager (1984) for LDCs, Rogers and Wang (1995), Moreno (1999), Kamin and Rogers (2000), Chou and Chao (2001) in the short run, and Bahmani-Oskooee and Miteza (2006) for 24 non-OECD countries]. Bahmani-Oskooee and Miteza (2003) provide a detailed survey of the literature. 
These previous works have made important contributions to the understanding of the subject and suggest that real depreciation or devaluation could be expansionary, contractionary, or neutral, depending on the country, time period, the formulation of a model, and the methodology employed in empirical work. To our knowledge, few of the previous articles have tested the hypothesis that real depreciation or appreciation may have a positive or negative affect on real output during different time periods.

\section{The Model}

Applying and extending Romer (2000, 2006), Taylor (1993, 1999), Svensson (2000), and other related studies, we can express an open-economy IS function, a monetary policy reaction function, and an augmented aggregate supply function as:

$$
\begin{aligned}
& Y=U(Y, R, G, T, E, W) \\
& R=V\left(\pi, Y, E, R^{*}\right) \\
& \pi=\pi^{*}+\delta\left(Y-Y^{\prime}\right)+\lambda E
\end{aligned}
$$

where

$$
\mathrm{Y}=\text { real GDP in Costa Rica, }
$$

$\mathrm{R}=$ the domestic real interest rate,

$\mathrm{G}$ = real government spending,

$\mathrm{T}=$ real government tax revenues,

$\mathrm{E}$ = real exchange rate measured as colones per U.S. dollar times the relative prices in the U.S. and Costa Rica,

$\mathrm{W}$ = world real income,

$\pi=$ the inflation rate,

$R^{*}=$ the world real interest rate,

$\pi^{*}=$ the expected inflation rate,

$Y^{\prime}=$ potential GDP in Costa Rica, and

$\delta, \lambda=$ parameters.

Solving three endogenous variables simultaneously, we can express equilibrium real GDP as:

$$
\bar{Y}=\bar{Y}\left(E, G, T, R^{*}, W, \pi^{*} ; \delta, \lambda, Y^{\prime}\right)
$$

The effect of real depreciation on equilibrium real GDP is given by:

$$
\partial \bar{Y} / \partial E=\left(U_{E}+\lambda U_{R} V_{\pi}+U_{R} V_{E}\right) /|J|<\text { or }>0
$$

where $|J|$ is the Jacobian for the endogenous variables and has a positive value. Note that the 
sign in (5) is ambiguous because the first term in the numerator is positive whereas the second and third terms in the numerator are negative.

The respective effects of a change in government deficit (G-T), $R^{*}, \mathrm{~W}$ and $\pi^{*}$ on equilibrium real GDP can be expressed as:

$$
\begin{aligned}
& \partial \bar{Y} / \partial G-\partial \bar{Y} / \partial T>0, \\
& \partial \bar{Y} / \partial R^{*}<0, \\
& \partial \bar{Y} / \partial W>0, \\
& \partial \bar{Y} / \partial \pi^{*}<0 .
\end{aligned}
$$

Hence, more government deficit, a lower world real interest rate, higher world real income, and a lower expected inflation rate would increase real output. Note that deficit-financed government spending may be ineffective due to Ricardian equivalence theory, crowding-out, uncertainties, and other related factors (Barro, 1989; Taylor, 2000).

\section{Empirical Results}

The source of the data came from the December 2009 issue of the International Financial Statistics, which is published by the International Monetary Fund. Real GDP is measured in billion colones at the 1991 price. The real exchange rate is represented by the units of the colon per U.S. dollar times the respective CPI indexes in the U.S. and Costa Rica. Thus, an increase means real depreciation of the colon, and vice versa. Due to lack of complete data for budget deficits, the ratio of government consumption spending to GDP is selected to represent fiscal policy. ${ }^{1}$ The real federal funds rate as measured by the difference between the federal funds rate and the U.S. inflation rate is chosen to represent the world real interest rate. World industrial output is used to represent world real income. It is an index with 2005 as the base year. The expected inflation rate is represented by a simple lagged inflation rate based on the consumer price index. In regression analysis, except for the variables with zero or negative values, all other variables are measured in the logarithmic scale. The sample ranges from 2000.Q1 to 2008.Q4. Quarterly data for real GDP before 2000.Q1 or after 2008.Q4 are not available or have not published. ${ }^{2}$

Figure 1 shows the scatter diagram between real GDP and the real exchange rate. When real GDP is relatively low, real depreciation leads to more real output. When real GDP is relatively high, real appreciation results in more real output. The threshold real GDP is approximately 440,000 billion colones. Although the scatter diagram shows a nonlinear bell shape, a hypothesis test is needed. Hence, a dummy variable is created with a value of 0 during 2000.Q1-2005.Q2 and 1 during 2005.Q3-2008.Q4. An interactive dummy variable is also generated to determine whether the slope coefficient of the real exchange rate may have changed.

According to the Augmented Dickey-Fuller (ADF) unit root test on the regression residuals, 


\section{Macrothink}

in absolute terms, the test statistic of -4.638 is greater than the critical value of -2.635 at the $1 \%$ level. Hence, these variables are cointegrated and have a long-run equilibrium relationship.

Figure 1: Scatter Diagram between Real GDP and the Real Exchange Rate

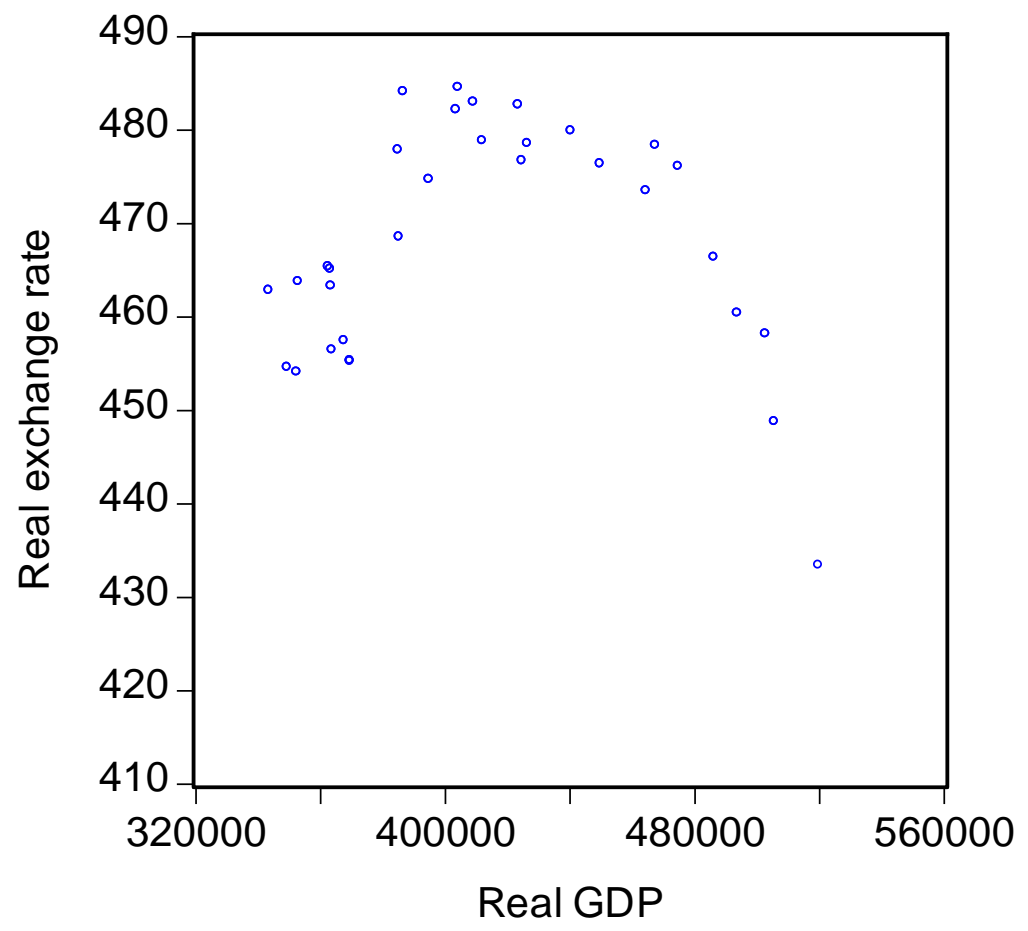

Table 1 presents estimated coefficients, standard errors, z-statistics, and other related statistics. Except for the dummy variable, the real federal funds rate, and the expected inflation rate with actual or potential zero or negative values, other variables are measured in the log scale. Note that the GARCH $(1,1)$ model is applied in empirical work because the residual variance is significantly affected by past squared residual and past residual variance. As shown, the seven right-hand side variables can explain $94.2 \%$ of the variation in real GDP. All the coefficients are significant at the $1 \%$ level. Real GDP is positively associated with the intercept dummy variable, the real exchange rate, and world real income and negatively influenced by the interactive dummy variable, the ratio of government consumption spending to GDP, the real federal funds rate, and the expected inflation rate. The slope coefficient during 2000.Q1-2005.Q2 is estimated to be 1.295, and the slope coefficient during 2005.Q3-2008.Q4 is estimated to be -0.616 (= 1.295 - 1.911). Specifically, if the colon has a 1\% real depreciation during 2000.Q1-2005.Q2, real output will increase 1.295\%; and if the colon has a 1\% real depreciation during 2005.Q3-2008.Q4, real output will decrease $0.616 \%$. The positive impact of real appreciation on real output during 2005.Q3-2008.Q4 suggests that the positive effect of increases in aggregate expenditures due to monetary easing outweighs any negative effect of a decrease in net exports. 
Table 1. Estimated Regression of Real GDP for Costa Rica

\begin{tabular}{|c|c|c|}
\hline Variable & Coefficient & z-Statistic \\
\hline $\mathrm{C}$ & 1.303 & 3.109 \\
\hline DUM & 11.944 & 14.387 \\
\hline LOG(E) & 1.295 & 16.222 \\
\hline DUMxLOG(E) & -1.911 & -14.189 \\
\hline LOG(GY) & -0.202 & -6.508 \\
\hline$R^{*}$ & -0.013 & -9.171 \\
\hline $\mathrm{LOG}(\mathrm{W})$ & 0.912 & 10.448 \\
\hline$\pi^{*}$ & -0.009 & -7.575 \\
\hline \multicolumn{3}{|c|}{ Variance Equation } \\
\hline $\mathrm{C}$ & $2.06 \mathrm{E}-05$ & 46.869 \\
\hline $\operatorname{RESID}(-1)^{\wedge} 2$ & 2.098 & 5.199 \\
\hline GARCH(-1) & -0.094 & -5.064 \\
\hline \multicolumn{3}{|c|}{$\begin{array}{ll}\text { Adjusted } \mathrm{R}^{2} & 0.942 \\
\end{array}$} \\
\hline F-statistic & \multicolumn{2}{|c|}{57.628} \\
\hline AIC & \multicolumn{2}{|c|}{-4.062} \\
\hline SC & \multicolumn{2}{|c|}{-3.578} \\
\hline \multicolumn{3}{|c|}{ Sample 2000.Q1-2008.Q4 } \\
\hline $\mathrm{N}$ & & \\
\hline
\end{tabular}

Notes:

The Dependent Variable is LOG(Y). C is the intercept term. DUM is the dummy variable with a value of 0 during 2000.Q1-2005.Q2 and 1 during 2005.Q3-2008.Q4. E is the real exchange rate measured as units of the colon per U.S. dollar times the relative prices in the U.S. and Costa Rica. An increase means real depreciation, and vice versa. GY is the ratio of government consumption spending to GDP. $R^{*}$ is the real U.S. federal funds rate. W is world real income. $\pi^{*}$ is the expected inflation rate.

\section{Summary and Conclusions}

This paper has examined the role of the real exchange rate and other factors in determining output fluctuations in Costa Rica. Applying the monetary policy reaction function and the interactive dummy variable technique, the paper has confirmed a bell-shaped relationship, suggesting that real depreciation increases real output in early years whereas real appreciation increases real output in later years. In addition, a lower ratio of government consumption spending to GDP, a lower real federal funds rate, higher world real income, and a lower expected inflation rate would increase real output. There are several policy implications. The authorities need to pursue fiscal prudence as expansionary fiscal policy is ineffective. The central bank needs to maintain transparency and independence in order to contain inflationary expectations due to its negative effect on real output. The Costa Rican economy would 
benefit as the Federal Reserve Bank maintains a relatively low federal funds rate and as the world economy would be gradually recovering from the global financial crisis.

There may be areas for future research. The expected inflation rate may be constructed in different manners. The real effective exchange rate (REER) may be considered. Because an increase in the real effective exchange rate means real appreciation, the scatter diagram between real GDP and the real effective exchange rate may show a U-shaped relationship. If the data are available, the real financial stock price may be considered as the wealth effect and the balance-sheet effect (Kuttner and Mosser, 2002) would influence consumption and investment expenditures. In the formulation of the model, the monetary policy function may be substituted by the conventional LM function, although Romer (2000) indicates the problems and challenges in its application.

\section{Footnotes}

1. Ideally, the government budget deficit should be used in the model. However, the data for the government budget deficit during 2003.Q1-2005.Q4 and after 2006.Q4 are not available in the latest International Financial Statistics. The ratio of government consumption spending to GDP measures the size of the government relative to overall economic activities and has been used as a proxy for fiscal policy by other studies such as Barro (1991) due to the unavailability of the budget deficit data.

2. A larger sample size would make statistical outcomes more reliable. Attempts were made to increase the sample size without success as the Global Financial Data is not subscribed by this institution and Penn World Table Version 6.3 does not publish the data of world real income and the budget deficit and does not provide quarterly data for all the variables.

\section{References}

Bahmani-Oskooee, M., \& Rhee, H.-J. (1997) Response of domestic production to depreciation in Korea: an application of Johansen's cointegration methodology, International Economic Journal, 11, 103-112.

Bahmani-Oskooee, M. (1998). Are devaluations contractionary in LDCs? Journal of Economic Development, 23, 131-144.

Bahmani-Oskooee, M., Chomsisengphet, S., \& Kandil, M. (2002). Are devaluations contractionary in Asia? Journal of Post Keynesian Economics, 25, 69-81.

Bahmani-Oskooee, M., \& Miteza, I. (2003). Are devaluations expansionary or contractionary: a survey article. Economic Issues, 8, 1-28.

Bahmani-Oskooee, M., \& Miteza, I. (2006). Are devaluations contractionary? evidence from panel cointegration. Economic Issues, 11, 49-64.

Bahmani-Oskooee, M., \& Kutan, A. M. (2008), Are devaluations contractionary in emerging economies of Eastern Europe? Economic Change and Restructuring, 41, 61-74.

Barro, R. J. (1989). The Ricardian approach to budget deficits. Journal of Economic Perspectives, 3, 37-54. 
Barro, R. J. (1991). Economic growth in a cross section of countries. Quarterly Journal of Economics, 106, 407-444.

Chou, W. L., \& Chao, C. C. (2001). Are currency devaluations effective? a panel unit root test. Economics Letters, 72, 19-25.

Christopoulos, D. K. (2004). Currency devaluation and output growth: new evidence from panel data analysis. Applied Economics Letters, 11, 809-813.

Edwards, S. (1986). Are devaluations contractionary? The Review of Economics and Statistics, 68, 501-508.

Gylfason, T., \& Risager, O. (1984). Does devaluation improve the current account?, European Economic Review, 25, 37-64.

Gylfason, T., \& Schmid, M. (1983). Does devaluation cause stagflation? The Canadian Journal of Economics, 25, 37-64.

International Monetary Fund (2009). Costa Rica: request for stand-by arrangement - staff report; staff supplement and statement; press release on the executive board discussion; and statement by the executive director for Costa Rica. Series: Country Report No. 09/134, April 29.

Kamin, S. B., \& Rogers, J. H. (2000). Output and the real exchange rate in developing countries: an application to Mexico. Journal of Development Economics, 61, 85-109.

Rogers, J. H., \& Wang, P. (1995). Output, inflation and stabilization in a small open economy: evidence from Mexico. Journal of Development Economics, 46, 271-293.

Krugman, P., \& Taylor, L. (1978). Contractionary effects of devaluation. Journal of International Economics, 8, 445-456.

Kuttner, K. N., \& Mosser, P. C. (2002). The monetary transmission mechanism: some answers and further questions. Federal Reserve Bank of New York Economic Policy Review, 8, 15-26.

Moreno, R. (1999). Depreciation and recessions in East Asia. Federal Reserve Bank of San Francisco Economic Review, 3, 27-40.

Romer, D. (2000). Keynesian macroeconomics without the LM curve. Journal of Economic Perspectives, 14, 149-169.

Romer, D. (2006). Advanced Macroeconomics. (3 ${ }^{\text {rd }}$ ed.). New York: McGraw-Hill/Irwin.

Svensson, L. E. O. (2000). Open-economy inflation targeting. Journal of International Economics, 50, 155-183.

Taylor, J. B. (1993). Discretion versus policy rules in practice. Carnegie-Rochester Conference Series on Public Policy, 39, 195-214.

Taylor, J. B. (1999). A historical analysis of monetary policy rules. In J. B. Taylor (Eds.), 


\section{Macrothink}

Research in Applied Economics

ISSN 1948-5433

2010, Vol. 2, No. 2: E1

Monetary Policy Rules. Chicago and London: University of Chicago Press, pp. 319-341.

Taylor, J. B. (2000). Reassessing discretionary fiscal policy. Journal of Economic Perspectives, 14, 21-36.

The Economist (2009). Country briefings: Costa Rica. ttp://www.economist.com/countries/CostaRica/profile.cfm?folder=Profile-Economic\%20Dat a.

Upadhyaya, K. P. (1999). Currency devaluation, aggregate output, and the long run: an empirical study. Economics Letters, 64, 197-202. 